\title{
The hidden power of corporations
}

\author{
A lesson from China
}

\section{Martin McKee professor of European public health ${ }^{1}$, Sarah Steele senior research associate ${ }^{2}$, David Stuckler professor of policy analysis and public management ${ }^{3}$}

\author{
${ }^{1}$ Department of Public Health and Policy, London School of Hygiene and Tropical Medicine, London, UK; ${ }^{2}$ Department of Politics and International \\ Studies, University of Cambridge, Cambridge, UK; ${ }^{3}$ Dondena Research Centre and Department of Policy Analysis and Public Management, University \\ of Bocconi, Milan, Italy
}

Mao Zedong famously said that "political power grows out of the barrel of a gun." As he was someone who looked to the Russian Revolution for inspiration while engaged in a war to liberate his country from Japanese occupation, his view was understandable. Yet power can be exerted in different ways and can be most effective when it is hidden, with decisions made behind closed doors, or even invisible, so that the decisions one person makes are influenced by another without them realising it. $^{2}$

The growing literature on what are termed "the commercial determinants of health" pays particular attention to the hidden and invisible forms of power, whereby large corporations use various methods to shape thinking about what are appropriate responses to the health consequences of their products. ${ }^{3}$ In the accompanying article, Susan Greenhalgh describes how the Coca-Cola Company came to dominate obesity policy in China even though its influence was obscured behind the public face of intermediaries (doi:10.1136/bmj.k5050). ${ }^{4}$

\section{Changing the conversation}

In the late 1970s, Coca-Cola took advantage of the opening of Chinese society to the international community, exploiting the then extremely limited opportunities for Chinese researchers to access funds to undertake studies or to develop links with Western counterparts. It was not, however, Coca-Cola that made the approaches to Chinese researchers. Instead it was an organisation called the International Life Sciences Institute-a name that combined ideas of health, academia, and international links while also forming a memorable acronym, ILSI. Yet ILSI was established by a Coca-Cola executive with substantial funding from the company.

As Greenhalgh describes, the ILSI "Focal Point in China" (ILSI-China) has been able to exert remarkable influence on development of obesity policy by promoting a narrative that all foods and drinks, including those produced by Coca-Cola, could be part of a healthy diet. What matters, it claims, is that individuals expend the calories they ingest by taking sufficient exercise. This was also the core message of the Global Energy Balance Network, also set up by Coca-Cola and with members well represented at the Chinese conferences supported by ILSI. Coca-Cola had viewed the network as a "weapon" to "change the conversation" about obesity to one that diverted attention from their products in what it portrayed as a "war between the public health community and private industry." 5

We now know that corporations make extensive use of third parties such as ILSI to create a dominant narrative that frames how issues are viewed and sets the boundaries within which responses are seen as "reasonable," while excluding the most effective measures-especially those that harm the interests of the corporations-from the agenda. Some have specific goals, such as the Center for Indoor Air Research, which sought to undermine the evidence on the dangers of secondhand smoke. ${ }^{6}$ Others use a broad based approach that includes promotion of individual choice over collective action, supporting often ineffective educational campaigns rather than the legal or regulatory measures that tackle price, availability, and marketing of their products. ${ }^{7}$ This is exemplified in the use of the term "nanny state" to attack many of the most effective public health measures. ${ }^{8}$ Their approach also emphasises the "complexity" of public health problems, implying that little can be done to tackle them, applying the same language to issues as diverse as junk food, gambling, and asbestos. ${ }^{9}$

This approach also downplays potential conflicts of interest. Industry funded reports contend that everyone is in some way conflicted-for example, in holding certain political views-and that as long as funding is declared any conflicts are easily managed. If everyone is conflicted, there is no cause for concern..$^{10}$ Yet a wealth of evidence shows that industry funded studies tend to reach conclusions favourable to their sponsors ${ }^{11}$ and that disclosure of funding alone is inadequate, as researchers may exaggerate their findings and reviewers discount the potential for bias. ${ }^{12}$

ILSI's activities in China are similar to those it pursues elsewhere, which have long raised concerns. In 2001 a World 
Health Organization report condemned its links to the tobacco industry. ${ }^{13}$ A 2002 paper described ILSI's involvement in research partnerships as a "threat to scientific integrity." ${ }^{14}$ Yet, despite this information being freely available, ILSI's 18 constituent bodies continue to be influential around the world.

\section{Changing attitudes}

There are, however, signs that attitudes are changing. Recently, the food company Mars pulled out of ILSI, noting concern about its "advocacy led studies" that "mostly for the right reasons, have been criticized." ${ }^{15}$ The new Philip Morris funded Foundation for a Smoke Free World has attracted much adverse comment, ${ }^{16}$ and many universities and public health associations have stated that they will not accept funding from it. The US National Institutes of Health has withdrawn from an alcohol industry funded project on moderate drinking and issued new guidelines for such partnerships. ${ }^{17}$ The UK Charity Commission is questioning the status of some of the think tanks that have been most active in supporting the narrative of corporations ${ }^{18}$ but refuse to publish details of their funders. ${ }^{19}$ Yet, as the recent heavily criticised decision by Public Health England to partner with the alcohol industry funded charity Drinkaware shows, this message has not got through to everyone. ${ }^{20}$

Competing interests: We have read and understood BMJ policy on declaration of interests and have no relevant interests to declare.

Provenance and peer review: Commissioned; not externally peer reviewed.

Oxford concise dictionary of quotations. Oxford University Press, 2010 Lukes S. Power. Palgrave Macmillan, 1974.

McKee M, Stuckler D. Revisiting the corporate and commercial determinants of health. Am J Public Health 2018;108:1167-70. 10.2105/AJPH.2018.304510 30024808
4 Greenhalgh S. Making China safe for Coke: how Coca-Cola shaped obesity science and policy in China. BMJ 2019;354:k5050. 10.1136/bmj.k5050.

5 Barlow P, Serôdio P, Ruskin G, McKee M, Stuckler D. Science organisations and Coca-Cola's 'war' with the public health community: insights from an internal industry document. J Epidemiol Community Health 2018;72:761-3. 10.1136/jech-2017-210375 29540465

6 Barnes DE, Bero LA. Industry-funded research and conflict of interest: an analysis of research sponsored by the tobacco industry through the Center for Indoor Air Research. J Health Polit Policy Law 1996;21:515-42. 10.1215/03616878-21-3-515 8784687

7 Williams R, Alexander G, Aspinall R, etal . Gathering momentum for the way ahead: fifth report of the Lancet Standing Commission on Liver Disease in the UK. Lancet 2018;392:2398-412. 10.1016/S0140-6736(18)32561-3 30473364

8 Coggon J. The nanny state debate: a place where words don't do justice. Faculty of Public Health, 2018.

9 Petticrew M, Katikireddi SV, Knai C, etal . 'Nothing can be done until everything is done': the use of complexity arguments by food, beverage, alcohol and gambling industries. $J$ Epidemiol Community Health 2017;71:1078-83.28978619

10 McCambridge J, Daube M, McKee M. Brussels Declaration: a vehicle for the advancement of tobacco and alcohol industry interests at the science/policy interface? Tob Control 2019;28:7-12.29941544

11 Lundh A, Lexchin J, Mintzes B, Schroll JB, Bero L. Industry sponsorship and research outcome. Cochrane Database Syst Rev 2017;2:MR000033.28207928

12 Cain DM, Loewenstein G, Moore DA. The dirt on coming clean: perverse effects of disclosing conflicts of interest. J Legal Studies 2005;34:1-25.10.1086/426699.

13 Tobacco Free Initiative. The tobacco industry and scientific groups. ILSI: a case study. WHO, 2001. http://www.who.int/tobacco/media/en/LSI.pdf

14 James JE. Third-party threats to research integrity in public-private partnerships. Addiction 2002;97:1251-5. 10.1046/.1360-0443.2002.00146.x 12359027

15 Michail N. Breaking away from bad science? Mars to leave ILSI in transparency bid. 2018. https://www.foodnavigator.com/Article/2018/02/08/Breaking-away-from-bad-science-Marsto-leave-ILSI-in-transparency-bid

16 Daube M, Moodie R, McKee M. Towards a smoke-free world? Philip Morris International's new Foundation is not credible. Lancet 2017;390:1722-4. 10.1016/S0140-6736(17)32561-8 29047432

17 Rabin RC. NIH to scrutinize private donations to scientific research projects. 2018. https: //www.nytimes.com/2018/12/13/health/nih-alcohol-study.html

18 Townsend M, Evans R. Watchdog slams IEA over pro-Brexit report backed by Jacob Rees-Mogg. Guardian 2018 Dec 1. https://www.theguardian.com/politics/2018/dec/01/ iea-brexit-jacob-rees-mogg-charity-commission

19 Who Funds You. The UK campaign for think tank transparency. 2018. http://whofundsyou. org

20 Petticrew M, McKee M, Marteau TM. Partnerships with the alcohol industry at the expense of public health. Lancet 2018;392:992-3. 10.1016/S0140-6736(18)32320-1 30264711

Published by the BMJ Publishing Group Limited. For permission to use (where not already granted under a licence) please go to http://group.bmj.com/group/rights-licensing/ permissions 